\title{
Helping or hurting the harvest?
}

\author{
Book review by Rachel K. Pilloff, Esq.*
}

Lowe Hauptman \& Ham, LLP

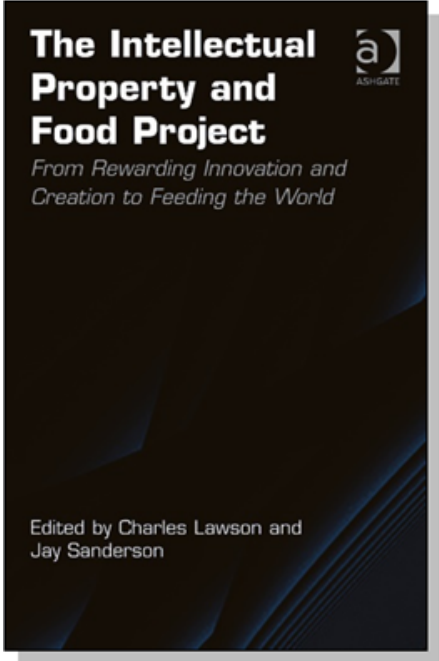

\author{
Review of The Intellectual Property and Food Project: From \\ Rewarding Innovation and Creation to Feeding the World, \\ edited by Charles Lawson and Jay Sanderson. (2013). Farnham, \\ Surrey, UK, and Burlington, Vermont: Ashgate. Available as \\ hardcover and ebook; 256 pages. Publisher's website: \\ http://www.ashgate.com/isbn/9781409469568
}

Published online May 4, 2015

Citation: Pilloff, R. K. (2015). Helping or hurting the harvest? [Book review]. Journal of Agriculture, Food Systems, and Community Development, 5(3), 157-158. http://dx.doi.org/10.5304/jafscd.2015.053.004

Copyright (C) 2015 by New Leaf Associates, Inc.

$\mathrm{W}$ hile many books address the role of intellectual property and goods, they generally address consumer goods such as small electronics, including telephones, computers, and the like. Despite the fundamental role of food and agriculture in our daily lives, very little scholarship evaluates the dynamics between food and intellectual property. The Intellectual Property and Food Project sows the first seeds for discussions on this topic, which I hope will cross-pollinate across the academic, legal, and business sectors so that much benefit can be harvested around the globe.

As its title suggests, The Intellectual Property and

\footnotetext{
* Rachel K. Pilloff is partner and registered U.S. patent attorney at Lowe Hauptman \& Ham, LLP, in Alexandria, Virginia, USA. Rachel has substantial experience representing plant breeders and has cultivated a varied and deep practice encompassing all aspects of plant patenting and licensing in the U.S. and across the globe. She can be contacted at rpilloff@ipfirm.com
}

Food Project developed from an academic workshop hosted by Griffith University's Australian Centre for Intellectual Property in Agriculture (ACIPA). The workshop was a conversation starter: academics interested in food and intellectual property began discussing the many ways food and intellectual property interact. Realizing that many more discussions could advance our understanding of this dynamic relationship, the workshop participants agreed that a book would provide the foundation for further discussions. Hence they planted the seeds and germinated The Intellectual Property and Food Project.

Before launching too far into the language of intellectual property and treaties, the book provides an overarching definition of food. In its simplest form, the book defines food as "any substance ingested by humans, is of plant or animal origin, and provides nutrients to the human body in the form of carbohydrates, proteins, fats, vitamins, and minerals" (p. 3). And yet despite its simplicity, food 
is anything but simple: food has inspired wars and slave trade, motivated the discovery of new lands, and continues to affect business, science, technology, and health.

Because the book stemmed from a workshop with diverse academics and somewhat divergent fields of study, the editors divide the book into four main parts: Observations from the Laboratory (Molecular Genetics and Food); Public Research and Plant Germplasm; Social, Economic, and Political Aspects of Food and Intellectual Property; and Access and Distribution (Intellectual Property, Food, and Practice). While the editors attempt to provide some cohesion between the sections, unfortunately the book reads much like an academic workshop, where one section does not necessarily bear immediate relation to the section preceding or following it.

Observations from the Laboratory: The book begins with the science and, notably, the role that advances in molecular biology play in crop and animal breeding. Genetic technologies such as gene identification and genome sequencing provide important information for trait development, which can be harnessed for improving and/or increasing food supply. While molecular genetics offers great opportunities for producing crops or feed with improved characteristics, intellectual property should promote rather than stifle innovation. While this section provides a comprehensive overview of the underlying science, it could benefit from a paring down of the science, as much of the cited scientific literature is from one named author and is also somewhat dated.

Public Research and Plant Germplasm: Harnessing the theme that intellectual property should encourage and not hinder innovation, the book next considers the changing role of publicly funded agriculture. Traditionally, publicly funded agriculture bore no relation to intellectual property, leaving patents and licenses to the for-profit, private sector. As the authors aptly note, intellectual property at best has done little to remedy poverty and hunger, and at worst has restricted access and increased prices. For example, high-yielding plant varieties or herbicide-resistant plants find little utility in subsistence agriculture due to lack of fertilizers or other needed inputs for these varieties to grow, and yet because they are frequently covered by patent claims, their access and propagation is limited by license and high costs. Because publicly funded agriculture is essentially agriculture for and by the people, however, it continues to explore strategies for acting as a public trustee of agriculture. Some of these strategies involve intellectual property-not as a source of revenue, but as a source of public trust and availability.

Social, Economic, and Political Aspects of Food and Intellectual Property: The book outlines key international treaties and protocols, such as the Agreement on Trade-Related Aspects of Intellectual Property (TRIPS), Convention on Biological Diversity, Plant Treaty, Nagoya Protocol, and their sometimes conflicting roles in open access. The authors provide an in-depth review and analysis of this issue and emphasize that some form of an open-access regime(s) will help secure food sovereignty, security, and protection of plant and animal diversity. While lengthy, this section reads very well and provides a comprehensive and historical review of the relevant treaties and agreements.

Access and Distribution: The final section of the book considers the role that intellectual property plays in food security. Starting from the popular belief that robust intellectual property rights, such as patent and plant variety rights, catalyze technological development and incentivize innovation, the authors counter that developing new technology and producing more food is not the panacea for food insecurity. This is so because food insecurity involves complexities such as politics, economics, infrastructure, and a myriad of social problems.

Clearly, intellectual property can help but also hinder food security. There is no one-size-fits-all solution, and this text provides a good foundation for further discussion.

As a practicing intellectual property attorney in the fields of plant biology and agriculture, I think The Intellectual Property and Food Project provides a good introduction into patent law and would fit nicely into the academic classroom. While the book would be a conversation starter in the classroom, seasoned professionals may not glean much from the text, as the authors stop short of sharing new information or new ideas. 